\title{
Rare earth elements in surface sediments of a marine coast under heavy anthropogenic influence: The Bohai Bay, China
}

\author{
Yong Zhang, Xuelu Gao* \\ Key Laboratory of Coastal Environmental Processes and Ecological Remediation, Yantai Institute of Coastal Zone Research, Chinese Academy of Sciences, \\ Yantai, Shandong 264003, China
}

\section{A R T I C L E I N F O}

\section{Article history:}

Received 20 December 2014

Received in revised form

10 July 2015

Accepted 15 July 2015

Available online 16 July 2015

\section{Keywords:}

Trace elements

Chemical fractionation

Sediment analysis

Coastal environment

\begin{abstract}
A B S T R A C T
Surface sediments along four river-to-sea transects from the coastal Bohai Bay were assessed using a four-step sequential extraction procedure to determine the concentrations of rare earth elements (REEs) and the geochemical fractions in which those elements were present. The concentrations of light REEs were slightly depleted than those of the middle REEs and the heavy REEs. No significant Ce anomaly was observed whereas slight Eu-positive anomaly was found. The sequential extraction results revealed that the geochemical fractions of REEs followed the order of residual $>$ reducible $>$ oxidizable $>$ acid soluble. The residual fraction accounted for the majority of the total concentrations of REEs. Middle REEs were more easily leached than other REEs. No obvious river-to-sea transportation was observed and the concentrations of REEs in surface sediments of the coastal Bohai Sea were consistent with the data from the Post-Archean Australian Shale. This study further demonstrated on the basis of our previous inference that the geochemical features of REEs in coastal sediments were generally unaffected by heavy anthropogenic effects.
\end{abstract}

() 2015 Elsevier Ltd. All rights reserved.

\section{Introduction}

The rare earth elements (REEs) are a coherent group of trace elements in the periodic table whose chemical properties are similar and change gradually and systematically with the increase of atomic number (Henderson, 1984; Dubinin, 2004). The coherent and predictable behavior of REEs, along with their sensitivity to $\mathrm{pH}$, redox conditions, and their tendency to participate in adsorption/ desorption reactions, allows them to be used for the interpretation of diagenetic redox conditions in palaeoenvironmental research (Shields and Stille, 2001), discriminating sediment provenance and evolution (Grousset et al.,1998; Xu et al., 2011, 2012), and elucidating seawater circulation patterns (Tachikawa et al., 1999), hydrothermal fluxes (German et al., 1999), and the historic oxygenation of the oceans (Henderson, 1984; Murray et al., 1992).

REEs exist naturally in coastal sediments but they can accumulate therein though river runoff, groundwater discharge and atmospheric deposition due to their use in industry and agriculture

\footnotetext{
* Corresponding author. Key Laboratory of Coastal Environmental Processes and Ecological Remediation, Yantai Institute of Coastal Zone Research, Chinese Academy of Sciences, No. 17 Chunhui Road, Yantai, Shandong 264003, China.

E-mail address: xlgao@yic.ac.cn (X. Gao).
}

(Strauch et al., 2008; Kulaksiz and Bau, 2011). Their environmental contamination has already been found in some mineralized areas and soils affected by the long-term application of sludge (Essington and Mattigod, 1990). Their effects on human health have also been documented, e.g. Gd accumulations can lead to kidney failure (Ergun et al., 2006), anaphylactic shock (Idee and Corot, 2008) and finally death (Kay, 2008). In recent years, the environmental behaviors of REEs have attracted increasing attention. Investigations of the background concentrations and geochemical fractionation of REEs in the environment including sediments, soils, and biological samples have been performed worldwide (e.g. Zhang et al., 1998; Leleyter et al., 1999; Cao et al., 2000; Zhang and Ishii, 2000; Yang et al., 2002; Borrego et al., 2005).

Approximately $97 \%$ of REEs are produced in China (U.S. Geological-Survey, 2011) and the industrial and agricultural usage of REEs has increased rapidly (Xie, 1991). Although REEs geochemistry in core sediments from the East China Sea (Xu et al., 2011) and the Bohai Bay (Xu et al., 2010) were studied, information about REEs especially the extent of anthropogenic effects on them in the Chinese coastal areas remains very scarce. Xu et al. (2012) investigated the fraction characteristics of REEs in surface sediments of the central Bohai Bay and deduced that the Haihe River may be a predominant source of REEs based on the similarity of 
their distribution patterns in different geochemical fractions in surface sediments between the Bohai Bay and the Haihe River.

In order to clarify the potential eco-environmental effects of extensive and intensive human activities from the surrounding areas, an investigation was carried out in the northwestern Bohai Bay, covering its intertidal and sublittoral zones and the lowermost reaches of the major rivers to which it connects. The geochemical characteristics of some environmental quality assessment related trace metals in surface sediments of this region indicated a general state that they were subject to apparent anthropogenic influence (Gao and Chen, 2012; Gao and Li, 2012), which was also the condition in many other areas along the coastal waters of the Bohai Sea (Gao et al., 2014). The results of this investigation also indicated that the REEs in the intertidal surface sediments of this region were generally unaffected by the heavy anthropogenic effects (Zhang et al., 2014). Although rivers transports both industrial and domestic waste effluents from the land to the sea, the role of rivers in conducting REEs from the land to the Bohai Bay has not yet been estimated. In the present study, both the concentrations and the fractionation of REEs in surface sediments of the coastal Bohai Bay from the major rivers it connects with to its coastal waters were determined to further evaluate the response of REEs to the anthropogenic effects from the surrounding areas in this region.

\section{Materials and methods}

\subsection{Description of the study area}

The Bohai Bay is located to the west of the Bohai Sea and covers an area of $1.58 \times 10^{4} \mathrm{~km}^{2}$, about one-fifth of the total area of the Bohai Sea (Fig. 1). The Bohai Bay is a shallow water basin with an average depth of $12.5 \mathrm{~m}$ (range $5.6-34.0 \mathrm{~m}$ ) and a semi-diurnal tidal range of $0.5-2.5 \mathrm{~m}$. The width of the tideland of the Bohai Bay is $3-5 \mathrm{~km}$ and the mean velocity of the residual current is less than $0.1 \mathrm{~m} / \mathrm{s}$. The exchange of water between the Bohai Bay and the Bohai Sea is weak so the physical self-cleaning capacity of the Bohai Bay is very poor (Tao, 2006). The bottom has a very mild-slope bottom and most of its sediments are fine mud.

The coastal region surrounding Bohai Bay is one of the most densely populated and industrialized zones in China, where some megacities, i.e. Beijing, Tianjin and Tangshan, are located. Several rivers scatter along the coast of the Bohai Bay (Fig. 1), of which the Haihe River dominates land runoffs flowing into the Bohai Bay although its annual freshwater discharge had decreased from $8.20 \times 10^{8} \mathrm{~m}^{3}$ averaged over $1960-2010$ to $3.76 \times 10^{8} \mathrm{~m}^{3}$ averaged for 2010 and 2011 (The Ministry of Water Resources of P.R. China, 2011). Other smaller rivers with only minor runoffs are the Dou River, Jiyun River, Chaobai River, Yongdingxin River, Duliujian River, Qingjinghuang River, Ziyaxin River, and Beipaishui River. These rivers bring in both municipal sewages and agricultural drainage from surrounding area, leading to the deterioration of the Bay's ecosystem.

\subsection{Sampling}

A total of 42 surface sediment samples (top 0-5 to 0-10 cm) were collected from the northwestern coast of the Bohai Bay in May 2008 (Fig. 1). The sampling stations were arranged along the major rivers of this area extending from the land to the sea and formed four transects. The water depths of all sampling sites in marine region are less than $10 \mathrm{~m}$. The samples from the marine region were collected with a stainless steel grab sampler, and the samples from rivers were collected using a plastic spatula. The samples were placed in acid-rinsed polyethylene zipper bags and stored at $\sim 4{ }^{\circ} \mathrm{C}$ in the dark. Lab analyses were performed immediately after landing to minimize storage time.

\subsection{Analytical methods}

The fractionations of REEs were obtained using the sequential extraction procedure described by Rauret et al. (1999). The scheme partitions elements into four operationally defined geochemical fractions, including acid-soluble (exchangeable and bound to carbonates), reducible (bound to $\mathrm{Fe} / \mathrm{Mn}$ oxyhydroxides), oxidizable (bound to organic matter and sulfides) and residual (contained within lithogenic minerals). The details of the sequential extraction protocol used in this study have been described elsewhere in Gao et al. (2008, 2010) and Zhang et al. (2014).

Sample drying can reportedly change the solid phase distribution of trace elements (Rapin et al., 1986; Hjorth, 2004).

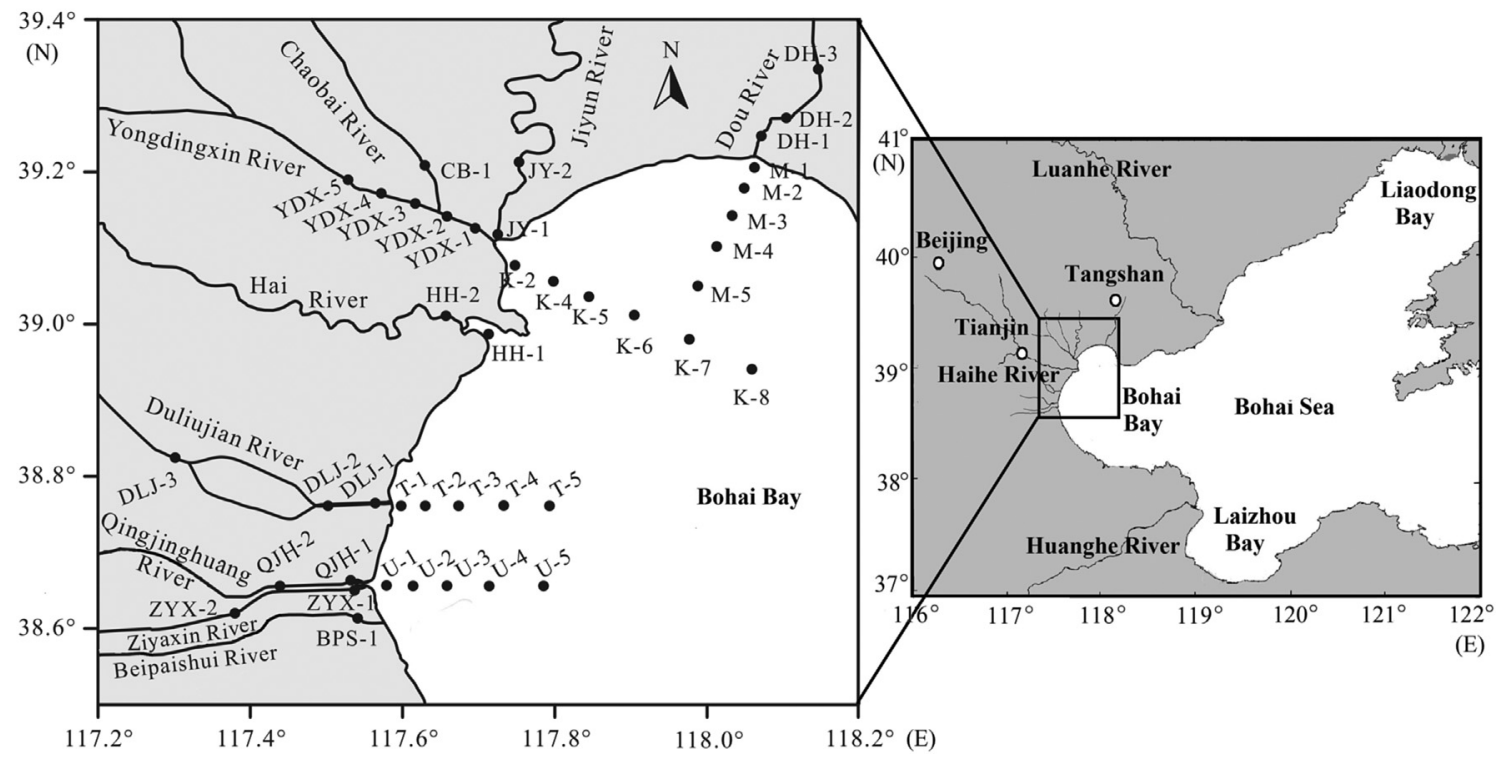

Fig. 1. Location of sampling sites in the coastal zone of the Bohai Bay. 
Additionally, the element concentrations in sediments depend strongly on the grain size (Horowitz and Elrick, 1988; Howari and Banat, 2001), and a triturating treatment can potentially alter the extractability of elements (Gilliam and Richter, 1988). Therefore, wet and unground sediments were used herein in the sequential extraction procedure to reduce errors.

After the third step of extraction, a mixture of concentrated HF, $\mathrm{HNO}_{3}$ and $\mathrm{HClO}_{4}$ (5:2:1; Li et al., 2000) was used to digest all of the remaining REEs in the residues instead of the so-called pseudototal digestion with aqua regia, which was used by Rauret et al. (1999). The total digestion of three randomly selected samples was performed by the same method as that used to determine the concentrations of REEs in the residual fraction. The total concentrations of REEs in sediments were estimated by summing up the results for the four fractions, and they were $90-110 \%$ of the values obtained in the total digestion experiment.

Inductively coupled plasma mass spectrometry (Thermo X Series II) was used to determine the concentrations of REEs in this work. Plasma CAL calibration standards (SCP Science, Canada) were used to make up a linear calibration curve. Five multi-element standards were used to make up a linear calibration curve. Standard solutions were run after every 30 samples to monitor and correct fluctuations of instrumental drift. The Chinese national geostandard samples of GSS- 1 and GSS- 8 were processed in the same way as the sample was processed to control the analytical quality. The results matched the reference values, and the differences were all within $10 \%$ (most of them within $5 \%$ ). All plasticware and glassware were pre-cleaned by soaking them in $10 \% \mathrm{HNO}_{3}(\mathrm{v} / \mathrm{v})$ for at least two days. They were then soaked and rinsed with deionized water. All chemicals used in the experiment were guaranteed to be reagent-grade or better. Blank determinations were conducted throughout the processes of total concentration analyses and sequential extraction. All data were corrected for the dry weight of the sample.

Sample's water content, expressed as percentage, was calculated by the difference of wet and dry weight divided by wet weight. Dry weight was determined gravimetrically by heating sample at $105{ }^{\circ} \mathrm{C}$ until a constant value was obtained. For each sample, the percentages of the following three groups of grain sizes were determined $<4 \mu \mathrm{m}$ (clay), 4-63 $\mu \mathrm{m}$ (silt), and >63 $\mu \mathrm{m}$ (sand) using an Malvern Mastersizer 2000 laser diffractometer that could analyze particles with sizes between 0.02 and $2000 \mu \mathrm{m}$. The total organic carbon (TOC) content in the sediments was obtained by subtracting the inorganic carbon content from the total carbon, which was determined using a Shimadzu TOC-V $\mathrm{V}_{\mathrm{CPH}} / \mathrm{SSM}-5000 \mathrm{~A}$ and an Elementar Vario MACRO Cube CHNS analyzer, respectively.

\section{Results and discussion}

\subsection{General characteristics of sediments}

The sediments were predominantly composed of silt (average $66.1 \%$, range $57.0 \%-78.7 \%$ ), followed by clay (average $28.6 \%$, range $11.6-40.6 \%)$ and sand $(<5 \%)$. For the three sediments from the Duliujian River, their fine fraction (clay + silt) contents decreased downriver, and the one from the station nearest to the sea (DLJ-1) had the lowest value among all the studied samples. The TOC contents varied from 0.9 to $7.2 \%$ of the dry sediment weight with an average of $2.3 \%$. The high TOC contents $(>2.5 \%)$ were all recorded at the riverine sampling stations. However, the difference among the samples from the marine region was insignificant $(1.6 \% \pm 0.3 \%)$. The TOC contents showed a clear decreasing trend from $5.9 \%$ to $1.1 \%$ seaward at the Dou River-M transect. Detailed information about these can be found in Gao and Chen (2012) and Gao et al. (2012).

\subsection{REE concentration in bulk sediments}

Table 1 presents the concentrations of REEs in surface sediments from the coastal Bohai Bay. At all stations, the concentrations of REEs followed the order of $\mathrm{Ce}>\mathrm{La}>\mathrm{Nd}>\mathrm{Pr}>\mathrm{Dy}>\mathrm{Sm}>$ $\mathrm{Gd}>\mathrm{Er}>\mathrm{Yb}>\mathrm{Eu}>\mathrm{Ho}>\mathrm{Tb}>\mathrm{Tm}>$ Lu .

The concentrations of light REEs (LREEs; La to Eu), heavy REEs (HREEs; Gd to Lu), and the total concentration of REEs ( $\Sigma$ REEs) at each sampling site are presented in Fig. 2. At DH-M transect, $\Sigma$ REEs concentration was found to be the lowest at DH-3 $\left(120.9 \mu \mathrm{g} \mathrm{g}^{-1}\right)$, increasing seaward up to $182.8 \mu \mathrm{g} \mathrm{g}^{-1}$ at $\mathrm{M}-2$, then decreasing at M3 and $\mathrm{M}-4$, and finally rising to a maximum of $193.1 \mu \mathrm{g} \mathrm{g}^{-1}$ at M-5. At YDX-K transect, $\Sigma$ REEs concentration increased from $182.0 \mu \mathrm{g} \mathrm{g}^{-1}$ at the upstream station YDX-5 to $222.7 \mu \mathrm{g} \mathrm{g}^{-1}$ at the downstream station YDX-1, which was a maximum value among all the stations. At the marine stations from $\mathrm{K}-2$ to $\mathrm{K}-8$, the concentrations of $\Sigma$ REEs displayed minor variations (153.5-168.2 $\mathrm{g} \mathrm{g} \mathrm{g}^{-1}$ ). $\Sigma$ REEs increased downstream from JY-2 to JY-1, while decreased downstream from HH-2 to HH-1. At DLJ-T transect, T-1 showed a minimum $\Sigma$ REE concentration (147.4 $\mu \mathrm{g} \mathrm{g}^{-1}$ ) and $\mathrm{T}-3$ showed a maximum value $\left(208.4 \mu \mathrm{g} \mathrm{g}^{-1}\right)$, while the Duliujian River showed medium values with a peak value at DLJ-2. At QJH-ZYX-U transect, $\Sigma$ REEs decreased downstream from $\mathrm{QJH}-2$ to QJH-1 while increased downstream from ZYX-2 to ZYX-1. ZYX-1 showed a peak value $\left(198.6 \mu \mathrm{g} \mathrm{g}^{-1}\right)$ while $\mathrm{U}-1$ showed a minimum value (159.3 $\left.\mu \mathrm{g} \mathrm{g}^{-1}\right)$.

LREEs $\left(153.7 \pm 17.4 \mu \mathrm{g} \mathrm{g}^{-1}\right)$ dominated the total concentration of $\Sigma$ REEs $\left(172.6 \pm 19.4 \mu \mathrm{g} \mathrm{g}^{-1}\right)$ and it was about 8.1 times that of HREEs $\left(18.9 \pm 2.2 \mu \mathrm{g} \mathrm{g}^{-1}\right)$ (Fig. 2). The variation of $\Sigma$ REEs closely matched that of LREEs, reflecting the determination of LREEs to $\Sigma$ REEs. Both $\Sigma$ REEs (172.6 $\mu \mathrm{g} \mathrm{g}^{-1}$ ) and ratio of LREEs/HREEs (8.13) fall within the range of the central Bohai Bay $\left(184.9 \mu \mathrm{g} \mathrm{g}^{-1}\right.$ and 8.79 , respectively, $\mathrm{Xu}$ et al., 2012), the Changjiang River (186.6 $\mu \mathrm{g} \mathrm{g}^{-1}$ and 9.20, respectively), the Huanghe River (148.0 $\mu \mathrm{g} \mathrm{g}^{-1}$ and 8.70 , respectively) (Yang et al., 2002), and Po River (136.4 $\mathrm{g} \mathrm{g}^{-1}$ and 8.00, respectively, Kramer et al., 2002).

The average $\Sigma$ REEs $\left(172.6 \mu \mathrm{g} \mathrm{g}^{-1}\right)$ in the surface sediments of the study area is consistent with the REEs abundance of the Chinese loess (171 $\mu \mathrm{g} \mathrm{g}^{-1}$; Zhao et al., 1990) and higher than those of the East China Sea sediment $\left(109.03 \mu \mathrm{g} \mathrm{g}^{-1}\right)$, the Yellow Sea sediment $\left(123.01 \mu \mathrm{g} \mathrm{g}^{-1}\right)$, and pelagic sediment (125.93 $\mathrm{g} \mathrm{g} \mathrm{g}^{-1}$ ) (Zhu et al., 2006). This result shows that REEs have obvious terrigenous succession.

However, no decreasing trend was found from the river to the sea along each transect and also no significant difference was found among the four transects, indicating that land runoff was not a significant way to input REEs to the Bohai Bay. This finding is quite different from other heavy metals such as $\mathrm{Cd}, \mathrm{Cr}, \mathrm{Cu}, \mathrm{Ni}, \mathrm{Pb}$ and $\mathrm{Zn}$ in this area, which show an obvious decreasing trend in the riverto-sea direction caused by fluvial transportation from surrounding land (Gao and Chen, 2012).

Atmospheric transport and deposition plays an important role in introducing trace elements into coastal ocean. Dissolved atmospheric input is suggested to account for about 30-130\% of REEs input to the oceans by rivers (Greaves et al., 2003). For the East China Sea and Yellow Sea, atmospheric fluxes of trace elements may exceed their riverine inputs (Chen et al., 2010). Wang (2003) studied the atmospheric REEs concentration above Beijing city and found that the enrichment factor of REEs against earth crust ranged from 3 to 10 and industrial plants (such as Yanshan Petrochemical Plant) were marked as significant point sources. So, we speculate that the REEs in this studied area may be introduced mainly via atmospheric transportation from surrounding anthropogenic activities. 
Table 1

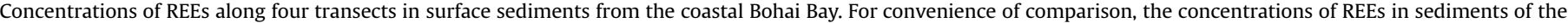
Changjiang River and Huanghe River (Yang et al., 2002) and Po River (Kramer et al., 2002) are also presented. Unit is $\mu g \mathrm{~g}^{-1}$ for all elements.

\begin{tabular}{|c|c|c|c|c|c|c|c|c|c|c|c|c|c|c|}
\hline Site & $\mathrm{La}$ & $\mathrm{Ce}$ & $\operatorname{Pr}$ & $\mathrm{Nd}$ & $\mathrm{Sm}$ & $\mathrm{Eu}$ & Gd & $\mathrm{Tb}$ & Dy & Ho & $\mathrm{Er}$ & $\mathrm{Tm}$ & $\mathrm{Yb}$ & $\mathrm{Lu}$ \\
\hline $\mathrm{DH}-3$ & 25.2 & 49.8 & 5.90 & 21.5 & 4.18 & 0.95 & 3.74 & 0.60 & 3.30 & 0.75 & 2.05 & 0.35 & 2.15 & 0.34 \\
\hline $\mathrm{DH}-2$ & 34.5 & 68.9 & 7.94 & 29.5 & 5.59 & 1.25 & 4.89 & 0.79 & 4.32 & 1.01 & 2.61 & 0.47 & 2.78 & 0.46 \\
\hline DH-1 & 34.1 & 70.7 & 7.93 & 29.7 & 5.94 & 1.21 & 4.83 & 0.82 & 4.54 & 1.03 & 2.72 & 0.51 & 2.83 & 0.44 \\
\hline M-1 & 34.1 & 70.8 & 8.20 & 30.8 & 6.32 & 1.28 & 5.34 & 0.85 & 4.82 & 1.08 & 2.80 & 0.51 & 2.93 & 0.47 \\
\hline M-2 & 37.8 & 77.3 & 8.77 & 32.3 & 6.27 & 1.33 & 5.38 & 0.87 & 4.84 & 1.10 & 2.80 & 0.51 & 3.08 & 0.48 \\
\hline M-3 & 34.2 & 68.2 & 8.20 & 30.6 & 5.54 & 1.24 & 5.02 & 0.78 & 4.21 & 1.00 & 2.70 & 0.47 & 2.69 & 0.43 \\
\hline M-4 & 32.4 & 62.5 & 7.29 & 28.3 & 5.32 & 1.07 & 4.54 & 0.74 & 3.87 & 0.91 & 2.52 & 0.42 & 2.50 & 0.42 \\
\hline M-5 & 37.3 & 77.9 & 8.58 & 32.4 & 6.42 & 1.32 & 5.15 & 0.87 & 4.90 & 1.10 & 2.91 & 0.54 & 3.22 & 0.49 \\
\hline Average & 33.7 & 68.3 & 7.85 & 29.4 & 5.70 & 1.21 & 4.86 & 0.79 & 4.35 & 1.00 & 2.64 & 0.47 & 2.77 & 0.44 \\
\hline SD & 3.9 & 8.9 & 0.91 & 3.5 & 0.73 & 0.13 & 0.53 & 0.09 & 0.56 & 0.12 & 0.27 & 0.06 & 0.33 & 0.05 \\
\hline JY-2 & 28.3 & 54.3 & 7.81 & 29.7 & 4.69 & 1.09 & 4.63 & 0.72 & 4.53 & 0.96 & 2.37 & 0.43 & 2.38 & 0.41 \\
\hline JY-1 & 37.2 & 71.8 & 8.20 & 31.4 & 6.07 & 1.25 & 5.04 & 0.88 & 4.52 & 1.06 & 2.82 & 0.49 & 2.91 & 0.46 \\
\hline CB-1 & 34.7 & 71.3 & 8.46 & 31.8 & 6.06 & 1.30 & 5.38 & 0.83 & 4.75 & 1.07 & 2.73 & 0.48 & 2.88 & 0.46 \\
\hline HH-2 & 38.4 & 74.3 & 8.59 & 35.0 & 6.52 & 1.33 & 5.78 & 0.93 & 4.83 & 1.13 & 3.06 & 0.52 & 3.08 & 0.51 \\
\hline HH-1 & 31.6 & 64.4 & 7.38 & 28.3 & 5.77 & 1.40 & 4.85 & 0.82 & 4.46 & 1.06 & 2.78 & 0.49 & 2.91 & 0.45 \\
\hline YDX-5 & 34.7 & 78.1 & 8.56 & 32.0 & 6.51 & 1.43 & 5.81 & 0.97 & 4.97 & 1.28 & 3.30 & 0.57 & 3.38 & 0.55 \\
\hline YDX-4 & 38.7 & 81.4 & 8.79 & 31.9 & 6.42 & 1.36 & 5.52 & 0.90 & 5.13 & 1.18 & 3.05 & 0.55 & 3.25 & 0.52 \\
\hline YDX-3 & 37.5 & 74.7 & 8.73 & 33.1 & 6.17 & 1.25 & 5.52 & 0.91 & 4.72 & 1.15 & 2.96 & 0.52 & 3.06 & 0.49 \\
\hline YDX-2 & 42.1 & 94.0 & 10.24 & 37.9 & 7.16 & 1.47 & 6.13 & 1.04 & 5.67 & 1.31 & 3.56 & 0.61 & 3.51 & 0.58 \\
\hline YDX-1 & 44.9 & 93.7 & 10.80 & 39.7 & 7.75 & 1.59 & 7.09 & 1.13 & 6.09 & 1.42 & 3.68 & 0.64 & 3.62 & 0.60 \\
\hline $\mathrm{K}-2$ & 31.3 & 62.9 & 7.48 & 28.2 & 5.42 & 1.14 & 4.95 & 0.80 & 4.23 & 0.98 & 2.73 & 0.45 & 2.61 & 0.44 \\
\hline $\mathrm{K}-4$ & 33.4 & 70.3 & 8.22 & 31.1 & 5.94 & 1.21 & 5.43 & 0.83 & 4.38 & 1.05 & 2.74 & 0.47 & 2.64 & 0.45 \\
\hline K-5 & 32.1 & 70.4 & 7.87 & 29.1 & 6.00 & 1.25 & 5.14 & 0.85 & 4.66 & 1.11 & 2.75 & 0.50 & 2.87 & 0.47 \\
\hline K-6 & 29.6 & 64.4 & 7.28 & 27.8 & 5.61 & 1.16 & 4.97 & 0.79 & 4.29 & 1.08 & 2.84 & 0.49 & 2.75 & 0.46 \\
\hline K-7 & 32.2 & 65.8 & 7.63 & 28.0 & 5.72 & 1.15 & 4.59 & 0.78 & 4.24 & 0.97 & 2.50 & 0.45 & 2.61 & 0.40 \\
\hline K-8 & 31.8 & 64.0 & 7.70 & 28.5 & 5.70 & 1.14 & 4.77 & 0.78 & 4.14 & 0.99 & 2.64 & 0.45 & 2.62 & 0.44 \\
\hline Average & 34.9 & 72.2 & 8.36 & 31.5 & 6.09 & 1.28 & 5.35 & 0.87 & 4.73 & 1.11 & 2.91 & 0.51 & 2.94 & 0.48 \\
\hline SD & 4.6 & 10.7 & 0.98 & 3.5 & 0.71 & 0.14 & 0.65 & 0.11 & 0.53 & 0.13 & 0.36 & 0.06 & 0.35 & 0.06 \\
\hline DLJ-3 & 34.9 & 66.1 & 7.87 & 29.4 & 5.71 & 1.20 & 4.95 & 0.77 & 4.25 & 0.93 & 2.49 & 0.44 & 2.51 & 0.41 \\
\hline DLJ-2 & 43.2 & 81.3 & 9.62 & 36.0 & 6.73 & 1.30 & 5.64 & 0.92 & 5.06 & 1.11 & 3.01 & 0.53 & 3.10 & 0.50 \\
\hline DLJ-1 & 38.0 & 71.7 & 8.14 & 30.4 & 5.91 & 1.21 & 4.92 & 0.85 & 4.81 & 1.06 & 2.84 & 0.52 & 2.97 & 0.47 \\
\hline $\mathrm{T}-1$ & 30.1 & 61.8 & 6.88 & 26.3 & 5.27 & 1.13 & 4.47 & 0.75 & 4.03 & 0.93 & 2.46 & 0.42 & 2.53 & 0.39 \\
\hline $\mathrm{T}-2$ & 33.0 & 71.9 & 8.00 & 30.2 & 6.05 & 1.32 & 5.36 & 0.90 & 4.81 & 1.20 & 3.11 & 0.53 & 3.15 & 0.52 \\
\hline $\mathrm{T}-3$ & 42.0 & 88.6 & 9.82 & 36.6 & 7.21 & 1.47 & 6.35 & 1.04 & 5.72 & 1.31 & 3.48 & 0.63 & 3.63 & 0.59 \\
\hline $\mathrm{T}-4$ & 31.1 & 71.8 & 7.66 & 29.6 & 6.11 & 1.26 & 5.26 & 0.87 & 4.88 & 1.12 & 2.94 & 0.54 & 3.09 & 0.49 \\
\hline $\mathrm{T}-5$ & 30.7 & 68.9 & 7.50 & 28.9 & 5.99 & 1.15 & 5.00 & 0.85 & 4.58 & 1.02 & 2.73 & 0.53 & 2.94 & 0.46 \\
\hline Average & 35.4 & 72.8 & 8.19 & 30.9 & 6.12 & 1.26 & 5.24 & 0.87 & 4.77 & 1.08 & 2.88 & 0.52 & 2.99 & 0.48 \\
\hline SD & 5.1 & 8.5 & 1.03 & 3.5 & 0.60 & 0.11 & 0.57 & 0.09 & 0.52 & 0.13 & 0.33 & 0.06 & 0.36 & 0.06 \\
\hline QJH-2 & 36.8 & 80.6 & 8.41 & 34.8 & 6.93 & 1.36 & 6.12 & 1.02 & 5.22 & 1.32 & 3.41 & 0.62 & 3.35 & 0.56 \\
\hline QJH-1 & 34.6 & 77.7 & 8.50 & 33.6 & 6.52 & 1.29 & 5.97 & 1.00 & 5.09 & 1.32 & 3.43 & 0.59 & 3.27 & 0.58 \\
\hline ZYX-2 & 34.1 & 65.7 & 7.90 & 29.8 & 5.65 & 1.17 & 4.92 & 0.81 & 4.13 & 1.01 & 2.75 & 0.49 & 2.68 & 0.46 \\
\hline ZYX-1 & 38.8 & 84.0 & 8.85 & 35.1 & 7.31 & 1.49 & 6.02 & 1.07 & 5.99 & 1.37 & 3.55 & 0.66 & 3.77 & 0.60 \\
\hline BPS-1 & 32.3 & 70.4 & 7.37 & 30.9 & 6.02 & 1.18 & 5.38 & 0.91 & 4.53 & 1.19 & 3.14 & 0.54 & 3.09 & 0.55 \\
\hline U-1 & 30.5 & 67.4 & 7.01 & 28.1 & 5.73 & 1.19 & 5.34 & 0.89 & 4.73 & 1.10 & 3.14 & 0.52 & 3.15 & 0.50 \\
\hline U-2 & 36.1 & 78.6 & 8.79 & 35.4 & 6.63 & 1.40 & 6.01 & 1.02 & 5.37 & 1.28 & 3.39 & 0.61 & 3.41 & 0.56 \\
\hline U-3 & 35.4 & 77.1 & 8.46 & 31.5 & 6.44 & 1.35 & 5.67 & 0.92 & 4.84 & 1.18 & 3.07 & 0.54 & 3.27 & 0.52 \\
\hline U-4 & 35.1 & 77.4 & 8.18 & 30.9 & 6.34 & 1.30 & 5.19 & 0.94 & 5.00 & 1.11 & 3.04 & 0.55 & 3.07 & 0.49 \\
\hline U-5 & 33.4 & 74.0 & 7.94 & 31.4 & 6.50 & 1.31 & 5.60 & 0.94 & 5.04 & 1.19 & 3.08 & 0.56 & 3.10 & 0.51 \\
\hline Average & 34.7 & 75.3 & 8.14 & 32.1 & 6.41 & 1.30 & 5.62 & 0.95 & 4.99 & 1.21 & 3.20 & 0.57 & 3.22 & 0.53 \\
\hline SD & 2.3 & 5.9 & 0.60 & 2.5 & 0.51 & 0.10 & 0.41 & 0.08 & 0.50 & 0.11 & 0.24 & 0.05 & 0.28 & 0.04 \\
\hline Total average & 34.7 & 72.3 & 8.18 & 31.1 & 6.10 & 1.27 & 5.30 & 0.87 & 4.73 & 1.11 & 2.92 & 0.52 & 2.98 & 0.49 \\
\hline SD & 4.0 & 9.0 & 0.89 & 3.3 & 0.67 & 0.12 & 0.60 & 0.11 & 0.55 & 0.14 & 0.35 & 0.06 & 0.36 & 0.06 \\
\hline Changjiang & 39.5 & 78.7 & 8.87 & 33.6 & 6.37 & 1.30 & 5.98 & 0.82 & 4.74 & 0.89 & 2.71 & 0.35 & 2.48 & 0.35 \\
\hline Huanghe & 31.0 & 61.8 & 7.15 & 26.9 & 5.02 & 0.97 & 4.92 & 0.65 & 3.90 & 0.72 & 2.29 & 0.30 & 2.16 & 0.30 \\
\hline Po River & 27.8 & 56.7 & 6.14 & 25.0 & 4.66 & 1.00 & 4.41 & 0.68 & 4.01 & 0.80 & 2.35 & 0.33 & 2.20 & 0.32 \\
\hline
\end{tabular}

\subsection{Normalization analysis}

To eliminate the so-called "Oddo-Harkins" effect, i.e. the evenodd variation in the natural abundance of elements and their isotopes, measured REE concentrations are normalized to their corresponding concentrations in the upper continental crust (Nozaki et al., 2000; Wood et al., 2006). The REE concentrations of PostArchean Australian Shale (PAAS) (Taylor and McLennan, 1985), which was commonly used in environmental and marine-related studies, were chosen for normalization.

The PAAS normalized REEs are presented in Fig. 3. Along four transects, averaged REE concentrations in the Dou River were slightly lower than those in $\mathrm{M}-1$ to $\mathrm{M}-5$ (0.91 vs. 1.02), JY-CB-HH-
YDX slightly higher than K-2 to K-8 (1.11 vs. 0.97), DLJ comparable to T-1 to T-5 (1.04 vs. 1.06), and QJH-ZYX-BPS comparable to U-1 to U-5 (1.14 vs. 1.11) (Fig. 3).

In both the riverine region and marine region, the normalized values varied around 1.0 and $\mathrm{Sm}-\mathrm{Lu}$ had higher values than $\mathrm{La}-\mathrm{Nd}$. Tm/PAAS always showed the highest values at each transect $(1.15 \pm 0.15$ at $\mathrm{DH}-\mathrm{M}$ transect, $1.24 \pm 0.14$ at YCX-K transect, $1.26 \pm 0.15$ at DLJ-T transect, $1.38 \pm 0.12$ at QJH-ZYX-U transect, respectively). Ce/PAAS showed the lowest values at DH-M transect $(0.86 \pm 0.11)$ and at YDX-K transect $(0.91 \pm 0.13)$. Nd/PAAS showed the lowest values at DLJ-T transect $(0.91 \pm 0.10)$ and La/PAAS showed the lowest values at QJH-ZYX-U transect $(0.91 \pm 0.06)$.

These results showed that the sampled area was not heavily 




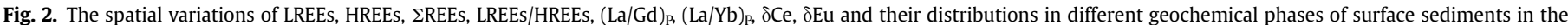
coastal Bohai Bay. The subscript P stands for PAAS.

contaminated by REEs. Both the normalized values and their distribution curve in this study were quite similar to the clayey silt sediments in the intertidal zone of the Bohai Bay as previously reported by Zhang et al. (2014), probably due to their similar material source and sedimentary environment evolution.

In surface sediments from the coastal Bohai Bay, the normalized concentration ratios of $\mathrm{La} / \mathrm{Gd}$ and $\mathrm{La} / \mathrm{Yb}$ were lower than 1.00 except at DLJ-2 and DLJ-3 (both were 1.03) (Fig. 2). The total average value of $\mathrm{La} / \mathrm{Gd}$ was $0.80 \pm 0.06$ and $\mathrm{La} / \mathrm{Yb}$ was $0.86 \pm 0.08$. The negative ratios indicated that the concentrations of LREEs were slightly depleted than the concentrations of middle REEs and HREEs. The total average value of $\mathrm{La} / \mathrm{Gd}(0.80)$ was quite in line with those in the sediments from the Changjiang (0.80), Huanghe $(0.80)$ and Po Rivers (0.80), while the total mean ratio of $\mathrm{La} / \mathrm{Yb}(0.86)$ was $4-28 \%$ lower $(1.20,1.10$, and 0.90 respectively) (Yang et al., 2002; Kramer et al., 2002).

$\mathrm{Ce}$ and $\mathrm{Eu}$ anomalies are widely observed because these two elements are present in nature not only as trivalent ions, like all other REEs, but also with other valences $\left(\mathrm{Ce}^{4+}\right.$ and $\left.\mathrm{Eu}^{2+}\right) \cdot \mathrm{Ce}^{3+}$ is subject to be oxidized to $\mathrm{Ce}^{4+}$ in oxygenated aqueous environment and $\mathrm{Ce}^{4+}$ tends to be more rapidly removed by particle scavenging than other REEs. Consequently, a relative depletion of Ce with respect to its REE neighbors La and Pr must occur (Sholkovitz et al., 1994; Nozaki et al., 2000). The anomalous behavior of Ce mentioned above is usually indicated by the so-called Ce anomaly $(\delta \mathrm{Ce})$, which is calculated as $\delta \mathrm{Ce}=2(\mathrm{Ce} / \mathrm{Ce}$ PAAS $) /\left[\left(\mathrm{La} / \mathrm{La} a_{\text {PAAS }}\right)+(\operatorname{Pr} /\right.$ $\left.\operatorname{Pr}_{\text {PAAS }}\right)$ ]. Diagenetic remobilization of Eu is possible under conditions of reduction to $\mathrm{Eu}^{2+}$ at low oxidation potential and $\mathrm{Eu}$ is reprecipitated in the $3+$ state in environments of high oxidation potential, yielding positive Eu anomalies in highly oxidized sediments (Macrae et al., 1992). Eu anomaly ( $\delta \mathrm{Eu})$ is calculated as the ratio of $\delta \mathrm{Eu}=2\left(\mathrm{Eu} / \mathrm{Eu}_{\mathrm{PAAS}}\right) /\left[\left(\mathrm{Sm} / \mathrm{Sm}_{\mathrm{PAAS}}\right)+\left(\mathrm{Gd} / \mathrm{Gd}_{\mathrm{PAAS}}\right)\right]$. The distributions of $\delta \mathrm{Ce}$ and $\delta \mathrm{Eu}$ are quite uniform with global average values of $0.99 \pm 0.05$ and $1.05 \pm 0.05$, respectively, showing no significant Ce anomaly and slight Eu anomaly (Fig. 2).

The $\delta \mathrm{Ce}$ in our present study are quite in line with those of the Changjiang River (1.00), Huanghe River (1.00), Po River (1.00) (Yang et al., 2002; Kramer et al., 2002) and the intertidal zone of the Bohai Bay reported in our early study (Zhang et al., 2014). Hoyle et al. (1984) suggested that Ce behaved coherently with its neighboring elements as a result of estuarine mixing so that Ce anomaly is not generated in estuary. The same result was also found in Elimbah Creek (Australia) by Lawrence and Kamber (2006).

Compared to the significant Eu-negative anomalies in the central Bohai Bay (Xu et al., 2012), the slight Eu-positive anomalies may be attributed to the well-oxygenated sediment in the coastal Bohai Bay due to shallow overlying water column. In addition, different nature of source rocks can lead to variation of Eu anomaly, sometime from negative to positive (Armstrong-Altrin et al., 2012, 2014, 2015). However, due to lack of data, we cannot discuss the possibility of source rocks-caused variation of $\mathrm{Eu}$ anomaly from coastal to central Bohai Bay herein.

\subsection{Fractionation}

Besides the total concentrations of metals, their physicochemical forms in sediments are also critical for evaluating their biogeochemical behaviors (Maiz et al., 2000; Gleyzes et al., 2002). 

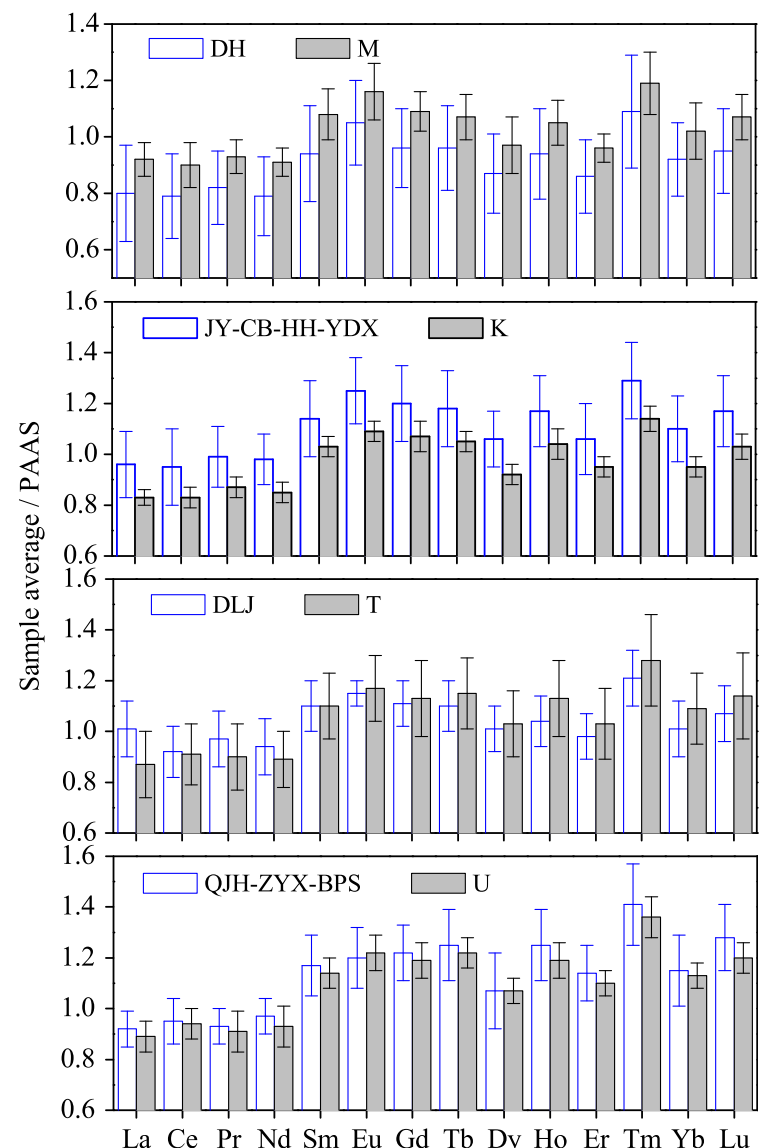

La Ce Pr Nd Sm Eu Gd Tb Dy Ho Er Tm Yb Lu Element

Fig. 3. PAAS-normalized REE patterns in surface sediments from the coastal Bohai Bay

Fig. 2 presents the percentages of the four geochemical fractions of REEs in surface sediments from the coastal Bohai Bay. At each site, the largest portion of REEs was associated with the crystalline lattices of minerals (residual fraction), followed by the fraction bound with $\mathrm{Fe}-\mathrm{Mn}$ oxides (reducible fraction), the fraction bound with organic matter (oxidizable fraction), and the fraction of exchangeable and bound with carbonates (acid soluble fraction) sequentially. Samples from the Duliujian River (DLJ 1-3) showed high residual fraction (ranging from $69.0 \%$ (Ho) to $83.1 \%(\mathrm{La})$ ) and low reducible and oxidizable fractions. Samples from the upstream Dou River (DH-2 and DH-3) displayed a minimum acid soluble fraction with a range of $0.24 \%(\mathrm{Ce})-2.8 \%$ (Eu). Samples from other sites presented similar percentages for each fraction, without apparent difference between the riverine and marine regions.

Averaged percentages of each REE geochemical fractions from the sampling sites in both the riverine and marine regions were presented in Fig. 4. In the riverine region, the average value of residual fraction accounted for $54.4 \%$ of their total concentration. The second largest was reducible fraction (32.2\%), followed by oxidizable fraction (11.1\%) and acid soluble fraction (2.3\%) (Fig. 4a). In the marine region, the fractions of REEs followed the same order as mentioned above with $52.9 \%$ in the residual fraction $(2.7 \%$ lower compared to riverine region), $34.0 \%$ in reducible fraction $(5.7 \%$ higher), $9.6 \%$ in the oxidizable fraction (13.7\% lower) and $3.5 \%$ in acid soluble fraction ( $50.4 \%$ higher) (Fig. 4 b).

The sequence of average concentrations of REEs in different geochemical fractions in surface sediments of the coastal Bohai Bay coincides with that of the central Bohai Bay reported by Xu et al.
(2012), although different sequential extraction method was used in their work and the acid soluble fraction was divided into exchangeable fraction and bound with carbonates fraction. Dominance of residual fraction indicated that most REEs were bound to mineral lattices in surface sediments of the coastal Bohai Bay, which was consistent with the finding that clay minerals are important reservoirs of REEs in Chinese coastal marine sediments (Zhao and Yan, 1994).

The percentages of residual fractions from $\mathrm{La}$ to $\mathrm{Lu}$ took on concave shapes, while other fractions took on convex shapes (Fig. 4), suggesting that middle REEs are more easily leached than other REEs. Many mechanisms have been presented to interpret the phenomenon of middle REEs enrichment in the non-residual fractions. Gosselin et al. (1992) proposed one potential fractionation mechanism as solid-liquid exchange, which includes primary ion exchange or adsorption/desorption on mineral surfaces. Wang et al. (1994) interpreted middle REE enrichment in the nonresidual fractions as being caused by the stability of the partially filled $4 \mathrm{f}$ electron shells in the REEs. The middle REE enrichment in the acid soluble and reducible fractions might be explained as a result of the middle REE enrichment in carbonate and $\mathrm{Fe}-\mathrm{Mn}$ coatings (Palmer, 1985). The middle REE enrichment in the oxidizable fraction may be explained by the complexing ability of REEs with several kinds of carboxylic acids which roughly follow convex shapes (Zhang et al., 1998).

\subsection{Correlation analysis}

Correlation matrix for REE parameters, grain sizes and TOC are presented in Table 2. In riverine samples, LREEs, HREEs, and $\Sigma$ REEs are positively related to clay and negatively related to silt, sand and TOC. While in marine samples, they are positively related to silt and negatively related to sand. LREEs/HREEs, $(\mathrm{La} / \mathrm{Gd}) / \mathrm{p}$ and $(\mathrm{La} / \mathrm{Yb}) / \mathrm{p}$ are negatively related to clay and positively related to sand in riverine samples, whereas they are positively related to sand and negatively related to TOC in marine samples. $\delta \mathrm{Ce}$ in riverine samples is positively related to clay and negatively related to sand, while in marine samples it is positively related to silt and TOC and negatively related to sand. $\delta \mathrm{Eu}$ is positively related to TOC in riverine samples. Both reducible and oxidizable REEs in riverine samples are positively related to clay and negatively related to sand, whereas residual REEs are negatively related to clay and positively related to sand. They present similar characteristics in marine samples. TOC in riverine samples is slightly related to oxidizable REEs in a positive way but in marine samples weakly related to residual REEs.

These results suggested that both grain size and TOC are key determinants to riverine and marine samples. Clay fraction is a more important carrier of REEs in riverine samples compared to that in marine samples. Since REE are strongly associated with organic matter, the negative relationship between LREE, HREE and REE and TOC in riverine samples may be attributed to the removal of REE-organic colloids, whereas the loss of statistic relationship between them in marine region may be due to coagulation of REEcontaining colloids caused by $\mathrm{pH}$ and salinity change during estuarine mixing (Hoyle et al., 1984; Shlokovitz, 1995) and/or frequent anthropogenic disturbation such as dredging (Feng et al., 2010).

\section{Conclusions}

This study investigated the concentrations of REEs and their chemical forms in surface sediments along four river-to-sea transects from the coastal Bohai Bay. Residual fractions of all REEs occupied the majority of their concentrations, whereas the exchangeable fraction was bound to $\mathrm{Fe} / \mathrm{Mn}$ oxides, organic matter and sulphides, and carbonate sequentially. Middle REESs are more 


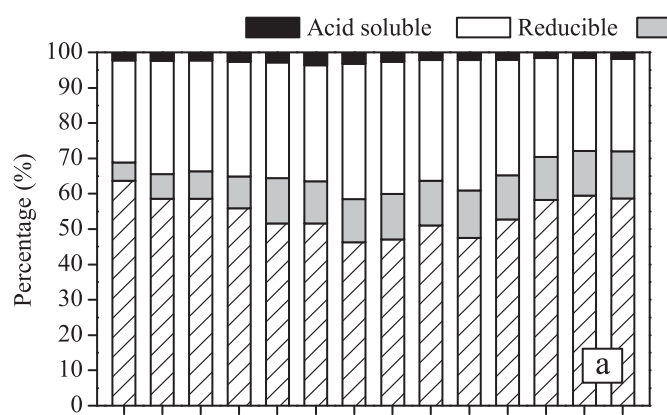

La Ce Pr Nd Sm Eu Gd Tb Dy Ho Er Tm Yb Lu Element

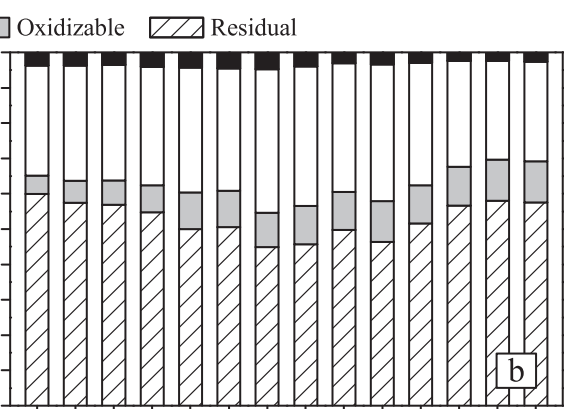

$\mathrm{La} \mathrm{Ce}$ Pr Nd Sm Eu Gd Tb Dy Ho Er Tm Yb Lu Element

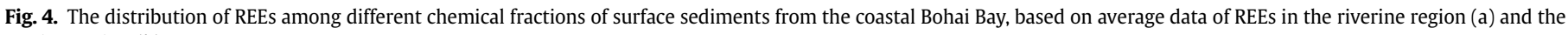
marine region (b).

\section{Table 2}

Pearson correlation matrix of REE parameters, grain size, and TOC in riverine and marine samples.

\begin{tabular}{|c|c|c|c|c|c|}
\hline Region & & Clay & Silt & Sand & TOC \\
\hline \multirow[t]{12}{*}{ Riverine samples } & LREEs $\left(\mu \mathrm{g} \mathrm{g}^{-1}\right)$ & $0.49^{c}$ & $-0.43^{c}$ & & $-0.63^{\mathrm{b}}$ \\
\hline & HREEs $\left(\mu \mathrm{g} \mathrm{g}^{-1}\right)$ & $0.67^{\mathrm{a}}$ & $-0.53^{c}$ & $-0.44^{c}$ & $-0.55^{\mathrm{b}}$ \\
\hline & LREEs $\left(\mu \mathrm{g} \mathrm{g}^{-1}\right)$ & $0.52^{\mathrm{c}}$ & $-0.44^{c}$ & & $-0.63^{\mathrm{b}}$ \\
\hline & LREEs/HREEs & $-0.44^{\mathrm{c}}$ & & & \\
\hline & $(\mathrm{La} / \mathrm{Gd})_{\mathrm{P}}$ & $-0.58^{\mathrm{b}}$ & & $0.56^{\mathrm{b}}$ & \\
\hline & $(\mathrm{La} / \mathrm{Yb})_{\mathrm{P}}$ & $-0.60^{\mathrm{b}}$ & & $0.50^{c}$ & \\
\hline & $\delta \mathrm{Ce}$ & $0.75^{\mathrm{a}}$ & & $-0.68^{a}$ & \\
\hline & $\delta \mathrm{Eu}$ & & & & $0.80^{\mathrm{a}}$ \\
\hline & Acid soluble REEs (\%) & & & & \\
\hline & Reducible REEs (\%) & $0.76^{\mathrm{a}}$ & & $-0.67^{a}$ & \\
\hline & Oxidizable REEs (\%) & $0.65^{\mathrm{a}}$ & & $-0.54^{\mathrm{c}}$ & $0.44^{\mathrm{c}}$ \\
\hline & Residual REEs (\%) & $-0.86^{\mathrm{a}}$ & $0.43^{c}$ & $0.72^{\mathrm{a}}$ & \\
\hline \multirow[t]{12}{*}{ Marine samples } & LREEs $\left(\mu g^{-1}\right)$ & & $0.43^{c}$ & $-0.41^{\mathrm{c}}$ & \\
\hline & HREEs $\left(\mu \mathrm{g} \mathrm{g}^{-1}\right)$ & & $0.48^{\mathrm{c}}$ & $-0.59^{b}$ & \\
\hline & LREEs $\left(\mu \mathrm{g} \mathrm{g}^{-1}\right)$ & & $0.44^{c}$ & $-0.44^{c}$ & \\
\hline & LREEs/HREEs & & & $0.42^{\mathrm{c}}$ & $-0.73^{\mathrm{a}}$ \\
\hline & $(\mathrm{La} / \mathrm{Gd})_{\mathrm{P}}$ & & & & $-0.68^{\mathrm{a}}$ \\
\hline & $(\mathrm{La} / \mathrm{Yb})_{\mathrm{P}}$ & & $-0.45^{c}$ & $0.68^{\mathrm{a}}$ & $-0.64^{\mathrm{b}}$ \\
\hline & $\delta \mathrm{Ce}$ & & $0.52^{c}$ & $-0.68^{a}$ & $0.56^{\mathrm{b}}$ \\
\hline & $\delta \mathrm{Eu}$ & & & & \\
\hline & Acid soluble REEs (\%) & & & & $0.49^{c}$ \\
\hline & Reducible REEs (\%) & & & & \\
\hline & Oxidizable REEs (\%) & $0.71^{\mathrm{a}}$ & & $-0.58^{\mathrm{b}}$ & \\
\hline & Residual REEs (\%) & $-0.56^{\mathrm{b}}$ & & & $-0.43^{c}$ \\
\hline
\end{tabular}

a $P<0.001$.

b $0.001<P<0.01$.

c $0.01<P<0.05$.

easily leached than other REEs. LREEs were slightly depleted compared to middle REES and HREES. The correlation analysis revealed that grain size and TOC were two important factors for the geochemical distributions of REEs in surface sediments of the coastal Bohai Bay. REEs were more abundant in sediments with finer grains. REE compositions in the coastal Bohai Sea were consistent with the data from the Post-Archean Australian Shale and no obvious river-to-sea transportation was found, indicating that the Bohai Bay was not highly polluted by REEs.

\section{Acknowledgments}

This investigation was supported by the National Natural Science Foundation of China (41376083). The assistance of Dr. J.H. Tang and the other people who participated in the sample collection and Mr. Y.Z. Wang in the laboratory work is greatly appreciated. The authors are also grateful to the reviewers for their comments and suggestions which were very helpful in improving this manuscript.

\section{References}

Armstrong-Altrin, J.S., Lee, Y.I., Kasper-Zubillaga, J.J., Carranza-Edwards, A., Garcia, D., Eby, N., Balaram, V., Cruz-Ortiz, N.L., 2012. Geochemistry of beach sands along the Western Gulf of Mexico, Mexico: implication for provenance. Chem. Erde Geochem 72, 345-362.

Armstrong-Altrin, J.S., Machain-Castillo, M.L., Rosales-Hoz, L., Carranza-Edwards, A. Sanchez-Cabeza, J.A., Ruíz-Fernández, A.C., 2015. Provenance and depositional history of continental slope sediments in the Southwestern Gulf of Mexico unraveled by geochemical analysis. Cont. Shelf Res. 95, 15-26.

Armstrong-Altrin, J.S., Nagarajan, R., Lee, Y.I., Kasper-Zubillaga, J.J., Córdoba-Saldaña, L.P., 2014. Geochemistry of sands along the San Nicolás and San Carlos beaches, Gulf of California, Mexico: implication for provenance and tectonic setting. Turk. J. Earth Sci. 23, 533-558.

Borrego, J., López-González, N., Carro, B., Lozano-Soria, O., 2005. Geochemistry of rare-earth elements in Holocene sediments of an acidic estuary: environmental markers (Tinto River Estuary, South-Western Spain). J. Geochem. Explor 86, 119-129.

Cao, X., Wang, X., Zhao, G., 2000. Assessment of the bioavailability of rare earth elements in soils by chemical fractionation and multiple regression analysis. Chemosphere 40, 23-28.

Chen, Y., Zhuang, G.S., Guo, Z.G., 2010. Atmospheric deposition of nutrients and trace elements to the coastal oceans: a review. Adv. Earth Sci. 25 (7), 682-690.

Dubinin, A.V., 2004. Geochemistry of rare earth elements in the Ocean. Lithol. Miner. Resour. 39, 289-307.

Ergun, I., Keven, K., Uruc, I., Ekmekci, Y., Canbakan, B., Erden, I., Karatan, O., 2006. The safety of gadolinium in patients with stage 3 and 4 renal failure. Nephrol. Dial. Transpl. 21, 697-700.

Essington, M.E., Mattigod, S.V., 1990. Element partitioning in size- and densityfractionated sewage sludge and sludge-amended soil. Soil Sci. Soc. Am. J. 54, 385-394.

Feng, H., Zhang, W.G., Jia, L., Weinstein, M.P., Zhang, Q.F., Yuan, D.K., Tao, J.H., Yu, L.Z. 2010. Short- and long-term sediment transport in western Bohai Bay and coastal areas. Chin. J. Oceanol. Limnol. 28, 583-592.

Gao, X.L., Chen, C.T.A., 2012. Heavy metal pollution status in surface sediments of the coastal Bohai Bay. Water Res. 46, 1901-1911.

Gao, X.L., Chen, C.T.A., Wang, G., Xue, Q.Z., Tang, C., Chen, S.Y., 2010. Environmental status of Daya Bay surface sediments inferred from a sequential extraction technique. Estuar. Coast. Shelf Sci. 86, 369-378.

Gao, X.L., Chen, S.Y., Long, A.M., 2008. Chemical speciation of 12 metals in surface sediments from the northern South China Sea under natural grain size. Mar. Pollut. Bull. 56, 786-792.

Gao, X.L., Li, P.M., 2012. Concentration and fractionation of trace metals in surface sediments of intertidal Bohai Bay, China. Mar. Pollut. Bull. 64, 1529-1536.

Gao, X.L., Yang, Y.W., Wang, C.Y., 2012. Geochemistry of organic carbon and nitrogen in surface sediments of coastal Bohai Bay inferred from their ratios and stable isotopic signatures. Mar. Pollut. Bull. 64, 1148-1155.

Gao, X.L., Zhou, F.X., Chen, C.T.A., 2014. Pollution status of the Bohai Sea, China: an overview of the environmental quality assessment related trace metals. Environ. Int. 62, 12-30.

German, C.R., Hergt, J., Palmer, M.R., Edmond, J.M., 1999. Geochemistry of a hydrothermal sediment core from the OBS ventfield, $21^{\circ} \mathrm{N}$ East Pacific Rise. Chem. Geol. 155, 65-75.

Gilliam, F.S., Richter, D.D., 1988. Correlations between extractable Na, K, Mg, Ca, P \& N from fresh and dried samples of two Aquults. Eur. J. Soil Sci. 39, 209-214.

Gleyzes, C., Tellier, S., Astruc, M., 2002. Fractionation studies of trace elements in contaminated soils and sediments: a review of sequential extraction procedures. Trend. Anal. Chem. 21, 451-467.

Gosselin, D.C., Smith, M.R., Lepel, E.A., Laul, J.C., 1992. Rare earth elements in chloride-rich groundwater, Palo Duro Basin. Texas, USA. Geochim. Cosmochim. Acta 56, 1495-1505.

Greaves, M.J., Statham, P.J., Elderfield, H., 2003. Rare earth element mobilization 
from marine atmospheric dust into seawater. Mar. Chem. 46, 255-260.

Grousset, F.E., Parra, M., Bory, A., Martinez, P., Bertrand, P., Shimmiled, G. Ellam, R.M., 1998. Saharan wind regimes traced by the Sr-Nd isotopic compositions of the subtropical Atlantic sediments: last glacial maximum vs. today. Quat. Sci. Rev. 17, 395-409.

Henderson, P. 1984. Rare Earth Element Geochemistry. Elsevier, Amsterdam.

Hjorth, T., 2004. Effects of freeze-drying on partitioning patterns of major elements and trace metals in lake sediments. Anal. Chim. Acta 526, 95-102.

Horowitz, A.J. Elrick, K.A., 1988. Interpretation of bed sediment traces metal data: methods for dealing with the grain size effect. In: Lichrenberg, J.J., Winter, J.A. Weber, C.I., Fradkin, L. (Eds.), Chemical and Biological Characterization of Sludges, Sediments Dredge Spoils, and Drilling Muds, pp. 114-128. ASTM STP 976, Philadelphia.

Howari, F.M., Banat, K.M., 2001. Assessment of Fe, Zn, Cd, Hg, and Pb in the Jordan and Yarmouk river sediments in relation to their physicochemical properties and sequential extraction characterization. Water Air Soil Pollut. 132, 43-59.

Hoyle, J., Elderfield, H., Gledhill, A., Greaves, M., 1984. The behaviour of the rare earth elements during mixing of river and sea waters. Geochim. Cosmochim. Acta 48, 143-149.

Idee, J.M., Corot, C., 2008. Anaphylactic shock after first exposure to a macrocyclic gadolinium chelate: a few comments. J. Allergy Clin. Immun. 122, 215-216.

Kay, J., 2008. Nephrogenic systemic fibrosis: a gadolinium-associated fibrosing disorder in patients with renal dysfunction. Ann. Rheum. Dis, 67 (3), 66-69.

Kulaksiz, S., Bau, M., 2011. Rare earth elements in the Rhine River, Germany: first case of anthropogenic lanthanum as a dissolved microcontaminant in the hydrosphere. Environ. Int. 37, 973-979.

Kramer, K.J.M., de Haan, E.P.M., van het Groenewoud, H., Dorten, W., Kramer, G.N., Muntaun, H., Quevauvillert, $\mathrm{Ph}, 2002$. Certified reference materials for the quality control of rare earth element determinations in the environment. Trend. Anal. Chem. 21, 762-773.

Lawrence, M.G., Kamber, B.S., 2006. The behaviour of the rare earth elements during estuarine mixing-revisited. Mar. Chem. 100, 147-161.

Leleyter, L., Probst, J.L., Depetris, P., Haida, S., Mortatti, J., Rouault, R., Samuel, J., 1999. REE distribution pattern in river sediments: partitioning into residual and labile fractions. Comptes Rendus l'Académie Sci. Series IIA, Earth Planet. Sci. 329, 45-52.

Li, X.D., Wai, O.W.H., Li, Y.S., Coles, B.J., Ramsey, M.H., Thornton, I., 2000. Heavy metal distribution in sediment profiles of the Pearl River estuary, South China. Appl. Geochem. 15, 567-581.

Macrae, N.D., Nesbitt, H.W., Kronberg, B.I., 1992. Development of a positive Eu anomaly during diagenesis. Earth Planet Sci. Lett. 109, 585-591.

Maiz, I., Arambarri, I., Garcia, R., Millan, E., 2000. Evaluation of heavy metal availability in polluted soils by two sequential extraction procedures using factor analysis. Environ. Pollut. 110, 3-9.

Murray, R.W., Ten Brick, M.R.B., Gerlach, D.C., Russ III, G.P., Jones, D.L., 1992. Interoceanic variation in the rare earth, major, and trace element depositiona chemistry of chert: perspectives gained from the DSDP and ODP record. Geochim. Cosmochim. Acta 56, 1897-1913.

Nozaki, Y., Lerche, D., Alibo, D.S., Snidvongs, A., 2000. The estuarine geochemistry of rare earth elements and indium in the Chao Phraya River, Thailand. Geochim. Cosmochim. Acta 64, 3983-3994.

Palmer, M.R., 1985. Rare earth elements in foraminifera tests. Earth Planet. Sci. Lett. 73, 285-298.

Rapin, F., Tessier, A., Campbell, P.G.C., Carignan, R., 1986. Potential artifacts in the determination of metal partitioning in sediments by a sequential extraction procedure. Environ. Sci. Technol. 20, 836-840.

Rauret, G., López-Sánchez, J.F., Sahuquillo, A., Rubio, R., Davidson, C., Ure, A. Quevauviller, P., 1999. Improvement of the BCR three step sequential extraction procedure prior to the certification of new sediment and soil reference materials. J. Environ. Monit. 1, 57-61.

Shields, G., Stille, P., 2001. Diagenetic constraints on the use of cerium anomalies as palaeoseawater redox proxies: an isotopic and REE study of Cambrian phosphorites. Chem. Geol. 175, 29-48.

Sholkovitz, E., Landing, W.M., Lewis, B.L., 1994. Ocean particle chemistry: the fractionation of the rare earth elements between suspended particles and seawater: Geochim. Cosmochim. Acta 58, 1567-1580.

Sholkovitz, E.R., 1995. The aquatic chemistry of rare earth elements in rivers and estuaries. Aquat. Geochem 1,1-34.

Strauch, G., Moder, M., Wennrich, R., Osenbruck, K., Glaser, H.R., Schladitz, T., Muller, C., Schirmer, K., Reinstorf, F., Schirmer, M., 2008. Indicators for assessing anthropogenic impact on urban surface and groundwater. J. Soil. Sediments 8 (1), 23-33.

Tachikawa, K., Jeandel, C., Roy-Barman, M., 1999. A new approach to the Nd residence time in the ocean: the role of atmospheric inputs. Earth Planet. Sci. Lett. $170,433-446$.

Tao, J.H., 2006. Numerical simulation of aquatic eco-environment of Bohai Bay. J. Hydrodyn. Ser. B 18, 34-42.

Taylor, S.R., McLennan, S.M., 1985. The Continental Crust: its Composition and Evolution. Blackwell Scientific Publication, Oxford.

The Ministry of Water Resources of P.R. China, 2011. Annual Report on Sediment Fluxes in Chinese Rivers: 2011. China Water Resources and Hydropower Publishing House, Beijing, China.

U.S. Geological-Survey, 2011. Mineral Community Summaries. U.S. Geological Survey, Reston, Virginia.

Wang, Z.W., 2003. Rare Earth Elements of Atmosphere and Effects of Rare Earth Elements on Emissions of Greenhouse Gases. Master's thesis. Guangxi University.

Wang, L.J., Li, X.X., Zhang, S., Zhang, C.S., 1994. A study on the contents and speciation of rare earth elements in the water body in the Wuhan section of the Yangtze River. Acta Geogr. Sin. 49 (4), 353-362.

Wood, S.A., Gammons, C.H., Parker, S.R., 2006. The behavior of rare earth elements in naturally and anthropogenically acidified waters. J. Alloy. Compd. 418, $161-165$.

Xie, H.G., 1991. Advance of applications of rare earth elements in agriculture in China. Chin. Sci. Bull. 36, 561-564.

Xu, FJ. Li, A.C., Li, T.G., Xu, K.H., Chen, S.Y., Qiu, L.W., Cao, Y.C., 2011. Rare earth element geochemistry in the inner shelf of the East China Sea and its implication to sediment provenances. J. Rare Earth 29 (7), 702-709.

Xu, Y.Y., Song, J.M., Duan, L.Q., Li, X.G., Zhang, Y., Sun, P.Y., 2010. Environmental geochemistry reflected by rare earth elements in Bohai Bay (North China) core sediments. J. Environ. Monit. 12, 1547-1555.

Xu, Y.Y., Song, J.M., Duan, L.Q., Li, X.G., Yuan, H.M., Li, N., Zhang, P., Zhang, Y., Xu, S.S. Zhang, M., Wu, X.D., Ying, X.B., 2012. Fraction characteristics of rare earth elements in the surface sediment of Bohai Bay, North China. Environ. Monit. Assess. 184, 7275-7292.

Yang, S.Y., Jung, H.S., Choi, M.S., Li, C.X., 2002. The rare earth element compositions of the Changjiang (Yangtze) and Huanghe (Yellow) river sediments. Earth Planet. Sci. Lett. 201, 407-419.

Zhang, C., Wang, L., Zhang, S., 1998. Geochemistry of rare earth elements in the mainstream of the Yangtze River, China. Appl. Geochem 13, 451-462.

Zhang, J., Ishii, T., 2000. Rare earth and trace element biogeochemistry of white clam in off Hatsushima cold seepage. JAMSTEC J. Deep Sea Res. 16, 155-161.

Zhang, Y., Gao, X.L., Chen, C.T.A., 2014. Rare earth elements in intertidal sediments of Bohai Bay, China: concentration, fractionation and the influence of sediment texture. Ecotoxicol. Environ. Saf. 105, 72-79.

Zhao, Y.Y., Wang, J.T., Qin, C.Y., Chen, Y.W., Wang, X.J., Wu, M.Q., 1990. Rare-earth elements in continental shelf sediments of the China Sea. Acta Sedimentol. Sin. 8 (1), 37-43 (in Chinese with English abstract).

Zhao, Y.Y., Yan, M.C., 1994. Geochemistry of Sediments in China Shallow Seas. Science Press, Beijing.

Zhu, L.M., Du, J.M., Zhang, Y.H., Xu, J., 2006. Tracing the sediment source at E2 hole in the South Yellow Sea with rare earth element and trace element. Acta Sci. Circumst. 26 (3), 495-500 (in Chinese). 